\title{
Brexit and Its Impact on Poland's Policy Towards Europe - An Attempt to Forecast
}

\begin{abstract}
Brexit has betrayed the disadvantages of the European project along with the fact that European institutions have no desire to conduct deeper reforms. Brexit cannot be considered without the stance that the British have developed not only in the last few years but generally over the period of its integration with continental Europe. A study shows the political consequences of the UK's exit from the European Union alog with the potential scenarios of Poland's European policy in the next 2-3 years. This article presents three scenarios for the development of Poland's European policy, i.e. the British scenario, a conservative scenario and a pro-European scenario. In addition, this article aims to show the potential activities of the Polish government in the context of selected scenarios for the development of the situation in Europe. Currently, the most likely is the British scenario, where the Polish government concentrates on those areas of integration that are important to it. The European Union will be treated by Poland as an economic organization providing access to the common European market as well as political support in the event of disputes with the powers. The adoption of the British scenario by Poland assumes an evolutionary drift towards polexit. The least realistic choice of scenario is the strongly pro-European approach. This would require a total change in Poland's European policy strategy and the abandoning of internal reforms.
\end{abstract}

Keywords: European Union, Brexit, Poland, Policy, Europe

\footnotetext{
^ Adrian Chojan - Lazarski University, e-mail: adrian.chojan@lazarski.pl, ORCID: 0000-0002-0132-1274.
} 


\section{Introduction}

The final decision of the UK to leave the European Union has set many important tasks for political decision-makers in Europe. One of them is not to lead to greater divisions on the Old Continent, and, consequently, perhaps to the collapse of the European Union. Many experts wrote about possible collapse of the EU even before the Brexit referendum itself, and before the formal decision of Britain to leave European family. ${ }^{1}$ However, in current situation the EU member states and its institutions have nothing left to do but pursue active policy towards greater integration. It should be remembered and emphasized that the Brexit process also has certain negative consequences for European integration. It is not said at all that British decision in the long run will not be the beginning of clear and, more importantly, further formal disintegration processes as a result of which some EU member states will lose the sense of their membership in this organization. It cannot be assumed that for all countries the European Union is the highest good that Europe has given Europe and it will last forever. However, it is currently difficult to conclude if a single event, such as the UK's exit from the EU, will lead to a significant deepening of disintegration, or maybe it will be just one of the cornerstones of this process or even its collapse. It seems that the implementation of any of these scenarios will have the greatest consequences for countries such as Poland, which, on the one hand, have gained a lot thanks to membership in the European Union but also could lose a lot if there was a clear deepening of disintegration, or even its final breakup . By the way, various development scenarios should be taken into account, including those presented by Ian Kearns, who writes about Europe after the European Union and potential effects of disintegration in Collapse: Europe After The European Union. ${ }^{2}$ Therefore, it is worth taking a look at several issues that raise a number of doubts. In my opinion, we should think about whether it is possible that the exit of the UK is an insignificant event and at the

1 More on this: W.J. Thies, Is the EU Collapsing?, „International Studies Review”, vol. 14, no. 2 (June 2012), pp. 225-239; J.M. Fiszer, Unia Europejska dziś i jej niepewna przyszłość. Część I (The European Union today and its uncertain future. Part I.), „Rocznik Integracji Europejskiej”, no. 9/2015, pp. 39-55; W. Orłowski, Scenariusze rozwoju Unii Europejskiej w kontekście zmian globalnych (European Union development scenarios in the context of global changes), in: Unia Europejska. Dylematy XXI wieku (European Union. 21st century dilemmas), eds. A. Kukliński, J. Woźniak, Urząd Marszałkowski Województwa Małopolskiego, Kraków 2011; M. Dahl, Y. Skomorokhova, The Balance of Power in the European Union after Brexit, „Studia Europaea” 2017.

2 More on this: I. Kearns, Collapse: Europe After The European Union, Biteback Publishing, London 2018. 
same time something that was simply expected? It is obvious that the country has always been looking for something different in Europe and interests or political visions regarding the form of cooperation differed with the ideas and thoughts of European supporters of integration. So why does a country like Poland, in which $89 \%$ of the population supports membership in the European Union, ${ }^{3}$ at some point choose Britain as the main partner in European politics, and what was the goal in the context of our membership in the EU? Finally, what consequences does Brexit have and will have for Poland and its European policy in the future?

The purpose of the study is to attempt to show Poland's potential place in the European Union in connection with Brexit and to analyze the development of future integration processes in Europe.

\section{Political Consequences of Brexit for the European Union}

Most experts make an effort to determine the consequences of Brexit for the European Union, which is the most obvious and common task. However, one should reverse this trend and first ask a deceitful question: was/is Britain's departure from the European Union a surprise, and should it be a one? Should the European Union and its member states be prepared for it in any way? Analyzing the entire membership process, whether in the European Communities or later in the European Union, it is difficult to find a longer period in which Britain would think continentally when it came to the process of European integration. Starting from Winston Churchill, who spoke about the UK as a link between the US and Europe, through the hard and decisive policy of Margaret Thatcher rebuilding the importance and independence of the country. Then the "Third Way" of Tony Blair and Gordon Brown, and ultimately David Cameron, who advocated integration with continental Europe but in the British sense of the word it is difficult to clearly characterize British activity in the process of European integration. What is meant by this? In the British perspective, Europe seems to be only a tool for a specific purpose. However, this objective has specific limits, such as the level of social acceptance for deeper integration with continental Europe. Hence, throughout all the years of its presence in European integration structures, British concentration has been focused on common market issues and the benefits/losses it was bringing for the economy. Political relations were only the "casing" of the extremely instrumental treatment of the European Union, while not being strongly committed to the idea of

Postrzeganie Unii Europejskiej i jej instytucji (Perception of the European Union and its institutions), „Komunikat z badań CBOS”, no. 32/2020, p. 1. 
creating something more (e.g. deepening cooperation in EU foreign and security policy) than just a common market for the benefit of London. Although British politicians like David Cameron were saying: "I am not a British isolationist", this isolationism was at the heart of British membership. Therefore, the decision to withdraw from the EU was not (or at least should not be) a surprise for EU politicians. Furthermore, the EU and its decision-makers should be very well prepared for it. Were they really? The period of turbulent divorce negotiations confirmed that they were not. It might seem that after 2004 European leaders lost their strategic instinct: instead of planning future processes, they focused on the here and now integration process. Too much was devoted to new and defiant member states, such as Poland or Hungary, and too little to planning the vision of European integration in the perspective of 15-20 years. It has been forgotten, or underestimated that European integration is not a state but a process that does not have to take only one positive direction of development. It can be said that the British brutally verified the EU's preparation for future challenges, seriously opening an in-depth discussion about the further meaning of the existence of the European project, even if some member states, such as Germany or France, clearly rejected the consequences of the British referendum for the EU.

Undoubtedly, the effects of the 2016 referendum in the United Kingdom were, however, a shock for the entire European Union and its member states. Hardly anyone allowed for the possibility of final vote for the British to leave the European Union. Since then, many experts and commentators have tried to show possible consequences of this decision for both the British side and the European Union as an international organization. Starting from the general consequences of Brexit for the EU and the entire European integration process, one key element should be emphasized, which, in fact, was not specifically mentioned in the EU narrative until 2016. The result of the referendum and the subsequent effects of EU-British negotiations have shown that European integration is a two-way process and, what is important, a completely reversible process. Until the Treaty of Lisbon came into force, no one in practice thought that any country could leave the EU, even the UK, despite its open criticism of the European project. After 2009, when the well-known article 50 was included in the Treaty on European Union, it was realized in the EU that this is legally possible, but hardly anyone thought that it was practically feasible. David Cameron's assumption of the office of Prime Minister of the UK in May 2010 and related announcements of the referendum were also not taken too seriously by European politicians. Nevertheless, we can say that his speech of 23 January 2013, in which he initiated the referendum, 
was the beginning of reversing the process of European integration, despite the fact that David Cameron himself did not quite want to lead the UK to the withdrawal from the EU. His statement makes one think that it was a kind of defense of British membership in the European Union by indicating the directions of necessary changes in the process of European integration. He said: “(...) there are 3 major challenges confronting us today. First, the problems in the Eurozone are driving fundamental change in Europe. Second, there is a crisis of European competitiveness, as other nations across the world soar ahead. And third, there is a gap between the EU and its citizens which has grown dramatically in recent years. And which represents a lack of democratic accountability and consent that is - yes - felt particularly acutely in Britain. If we don't address these challenges, the danger is that Europe will fail and the British people will drift towards the exit. I do not want that to happen. I want the European Union to be a success. And I want a relationship between Britain and the EU that keeps us in it". ${ }^{4}$ Prime Minister Cameron drew attention to the fundamental problems of the European Union but considered them not from the point of view of the EU as an international organization, but from the perspective of a member state and the consequences related to further drift of the integration process. The reversal of the European integration process in this context referred to the need to adapt/repair/ modify it to the expectations of a member state, whereas the art. 50 TEU was a legal instrument for its practical implementation. In this context, Brexit has opened the door to other EU member states to leave it. In a situation where the state claims that integration process is going the wrong way, and it can't be fixed, the state makes the best decision for itself - it either stays in the EU or leaves it.

Let us note that by their decision the British basically doubted the sense of the existence of the nearly 60 -year integration process counting from the Treaties of Rome of March 25, 1957. This whole context creates a certain danger and also long-term consequences for the European Union. The art. 50 assumes that "any Member State may decide to withdraw from the Union in accordance with its own constitutional requirements". Pursuant to this provision, it is a member state that initiates the EU withdrawal. In this spirit, it can be poetically stated that the British "consumed the forbidden fruit and broke a kind of integration taboo", which was the widespread belief in the necessity and need to remain in the European Union. The exit of the United Kingdom from the European Union may therefore be (though not necessarily) a kind of

4 EU speech at Bloomberg, UK government's website, https://www.gov.uk/government/speeches/eu-speech-at-bloomberg (access 10.04.2020). 
a snowball for further disintegration processes in Europe. According to, among others Józef M. Fiszer "Brexit will weaken the European Union and inhibit integration processes in Europe. Anti-EU and Eurosceptic sentiment will increase, consisting in criticism of the European Union and strong opposition to it". ${ }^{5}$ Another possible consequence may be the acceleration of the so-called differentiated integration. Of these two potential effects of the British withdrawal from the EU, the latter, which is differentiated integration, is definitely a better solution. As Agnieszka $\mathrm{K}$. Cianciara writes, "the goal of differentiated integration is to deal with the diversity of Member States' priorities and to avoid political deadlock (...) and diversity does not mean the failure of the integration project as such". ${ }^{6}$ Analyzing the development of the European integration process since the biggest enlargement in history on May 1, 2004, it might seem that the mentioned diversity of member states' priorities is much bigger than before that date. This is primarily due to the background of some countries that joined the European Union in 2004 and in the following years. The future consequences of Brexit for the EU and the entire integration process should not be considered without taking into account the specificities of individual member states and, importantly, their attitude to changes in the EU. There is a group of member states that relatively critically refers to the directions in which the process of European integration is heading. It is not only Poland or Hungary, but also Italy that accuses the EU of helplessness during the migration crisis, and later the lack of proper coordination between member states on the fight against the Covid-19 pandemic and the resulting consequences for this country. ${ }^{7}$ Therefore, potential future consequences of Brexit must be considered in a much broader context than just the UK's withdrawal from the European Union. The dynamics of international processes, not only regional but also global challenges, such as the Covid-19 pandemic, and in a moment also social dissatisfaction with its consequences such as, for example, the inevitable rise in unemployment, may only deepen the doubts of other member states on the formula of cooperation that the EU has adopted. This, in turn, can be a catalyst for loosening the integration

5 J.M. Fiszer, Szanse i zagrożenia dla Unii Europejskiej po brexicie. Implikacje dla Polski (Opportunities and threats for the European Union after Brexit. Implications for Poland), „Myśl Ekonomiczna i Polityczna”, no. 4/2017, p. 225.

${ }^{6}$ A.K. Cianciara, $W$ poszukiwaniu alternatywnych modeli integracji: Europa jako klub klubów (In search of alternative integration models: Europe as a club of clubs), „Myśl Ekonomiczna i Polityczna”, no. 4/2015, pp. 167-168.

7 J. Szymańska, M. Szczepanik, Reakcja Unii Europejskiej na epidemię korona wirusa (The European Union's response to the Covid 19 epidemic), „Biuletyn PISM”, March 17, 2020. 
process, especially considering that Britain has already shown the way. It should be taken into account that there are enough reasons for the revival of national egoisms in Europe, because in some member states not much is needed to change the attitude of government towards EU membership, or at least change the official rhetoric.

The UK has shown EU member states that there is a way to withdraw from the organization partly on its own terms. It initiated the process of destruction of the European Union. However, this does not mean the beginning of the end of European integration process, which was mentioned in the introduction, at the moment its modification, at most. In fact, much will depend on the arrangement of EU-British relations over the next 3-5 years. As we know, there are several scenarios for their formation, starting from the Norwegian model, through the Swiss, the Turkish and the free-trade area. At the moment, the Swiss model would be the most favorable cooperation model for both the UK and the European Union. Its essence is bilateral agreements regulating Britain's access to the EU's common market divided into its sectors. Observing the divorce negotiations, it is difficult to suppose that one and comprehensive free trade agreement between the UK and the European Union establishing free trade area could be signed. The development of this new model of cooperation and its practical application by both parties will undoubtedly be of interest to EU member states, and not only because of the benefits/ losses it brings for their national economies. It will also be a kind of experimental field for some of them in the event of such decisions like the one made by the British in 2016. It should not be considered a priori that the UK's exit was a one-off event (although it can be anyway), which will not be repeated more often. Furthermore, only now the member states will begin the actual game to take Britain's place, or obviously to strengthen their position. It applies to both big and most influential countries, such as Germany and France, but also to countries such as Poland, which are still looking for their place in the European Union.

\section{Brexit and Poland: Scenarios of Poland's European Policy Development}

The open secret is that as soon as Britain withdrew from the European Union, an intra-EU game about taking its place began. This process is currently being slowed down by the global Covid-19 pandemic as the member states primarily focus on reducing its effects. In addition, the period of divorce negotiations between London and Brussels was not the most appropriate time for political skirmishes and attempts to take over 
the legacy after the British. Different member states adopted different attitudes over this period. In all this, Poland's attitude was very puzzling. Before the British referendum, in the words of the former Minister of Foreign Affairs, Witold Waszczykowski in 2016, Poland chose Britain as the main ally in European politics. According to the minister it was necessary to "maintain the dialogue and regular consultations at various levels with the most important European partners - first of all with Britain, with which we share not only the understanding of many important elements of the European agenda, but also a similar approach to the problems of European security". ${ }^{8}$ The decision taken by the British a few months after this speech by Minister Waszyczykowski was undoubtedly a big strike to Polish foreign policy. It also exposed unreflective decisions made within it and the lack of a proper "diagnosis" of international developments by the Polish Ministry of Foreign Affairs. Given the timing of the turn in the policy towards Europe, which is also related to the change of power in Poland and its takeover by the coalition of the United Right and President Andrzej Duda, it clearly showed what Polish activity in the European Union would look like. However, the British decision not only quickly verified the assumptions of the Polish government, but also significantly reduced Poland's alliance capabilities on the EU forum. Both Warsaw and London were supporters of the intergovernmental nature of EU cooperation, i.e. de facto a strong strengthening of the role of nation states in the entire decision-making process of the European Union. Both capitals were also relatively distrustful of the activities of the European Commission and loudly demanded changes in the way the European Union was managed, proposing, among others increasing the role of national parliaments. With the United Kingdom departure from the EU, Poland lost its powerful "intergovernmental" ally, which was the second EU economy and a key country in terms of the EU military potential.

It is also important to realize that Brexit has led to a real change in the balance of power in the decision-making process in the European Union, with Germany and France being its biggest beneficiaries. ${ }^{9}$ Strengthening German domination in Europe, while weakening the further process of European integration as a result of deepening internal problems is certainly not good news for Europe, but also for Poland, which is still at the stage

${ }^{8}$ Information of the Minister of Foreign Affairs on Polish Foreign Policy in 2016.

9 More on this: M. Kleinowski, The impact of Brexit on the member states' ability to build blocking coalitions in the Council, „Środkowoeuropejskie Studia Polityczne”, no. 2/2019, pp. 5-27; J. Szymańska, Sz. Zaręba, Wpływ brexitu na głosowanie w Radzie UE (The impact of Brexit on voting in the EU Council), „Biuletyn PISM”, 8.04.2019. 
of catching up with European leaders. As we know, not all decisions taken in the European Union have so far been beneficial to us. In the situation of Brexit, it will be extremely difficult for Polish authorities to find, for example, a number of member states to build a blocking coalition, or to push their arguments in the relations between the eurozone and noneurozone countries. Regardless, the authorities in Warsaw will be forced to choose a specific strategy for participating in European politics. The time for a new balance of power in Europe is also time for changes in Poland's European policy and in the next $2-3$ years it will be necessary to clearly define our attitude in the European Union and answer the question: why are we in the European Union and what do we want to achieve? At the moment there are three potential scenarios for shaping Poland's policy toward Europe, i.e.

1. British scenario,

2. conservative scenario,

3. pro-European scenario.

The British scenario of Poland's policy towards Europe would amount to concentration by the Polish government on the integration areas that are only important for Warsaw, i.e. cohesion policy, or agricultural policy. In this scenario, the European Union will be treated by Poland as an economic organization allowing access to the common European market, as well as political support in the event of disputes with the superpowers such as with the Russian Federation. This assumption, however, is burdened with some disadvantages, especially if we mention the possibility of the Polish government's impact on EU decision-making process. The Polish government's involvement in the disintegration process is followed by national egoism and concern primarily for its own national interest, and thus weakening the impact on common market decisions. The disadvantage of this strategy is the further widening of the gap between the Eurozone and the other member states. In Poland, there are no prospects for the adoption of the single currency in the long term, so the British model of European policy, naturally, taking into account the differences in the potential between London and Warsaw and the possibility of influencing the course of European affairs, will only push Poland down the European ladder of influential member states. The British had specific arguments at the EU forum, such as a strong economy or military potential, while Poland has no such arguments, or they are definitely weaker. The same applies to external relations and the aforementioned policy towards Russia. It can be assumed with a very high probability that in the era when the economic crisis is beginning, Germany 
and France will work more actively to reduce the sanctions imposed on Russia or even lift them completely. The goal of these countries will be to stimulate economic cooperation to the maximum level. In this situation, Poland will have to meet a completely new task (the question of whether it wants to), which is to find an effective way to influence the European Union's policy towards the Russian Federation, so as not to lose too much on deepening cooperation between the largest EU Member States and this country. Given the skills Poland has in terms of forming coalitions, especially among the so-called leading countries in the EU, this prospect is not very promising. On the other hand, from a political perspective, the adoption of the British model of European policy would actually assume the accumulation of actions aimed at limiting the role of Germany and France, which, with the increase in their importance in the EU decisionmaking system, would be very difficult, and might complicate Poland's position in the Union. Adoption of the British scenario by Poland assumes evolutionary drift towards Polexit. The British road to leave the EU was also evolutionary, and one of its main instruments was criticism of the way the EU operated and increasing interference in the internal affairs of the member states, and finally the reluctance of some citizens to the essence of membership. In Poland, only the last issue is for the time being a clear obstacle to starting a discussion on loosening Polish ties with the EU. In Poland, an additional determinant may be domestic policy and, for example, EU restrictions on the state of the rule of law in Poland and the related transfer of European funds in accordance with the principle of "money for the rule of law".${ }^{10}$ It also seems that the moment when the implementation of the British model in Polish European policy accelerates will be the change of Poland's position from a net beneficiary to a net contributor to the EU budget.

The second possible scenario, which is more conservative, assumes that Poland will wait out the difficulties in Europe and in the world related to the Covid-19 pandemic in the next 2-3 years. In this scenario, the concentration of governments in Poland would be aimed at eliminating the economic effects of the pandemic without further reforming the internal policy and not provoking European institutions to undertake drastic, including financial actions against Warsaw. In this scenario, Poland would stop criticizing European institutions and calm the voices

10 T. Bielecki, Spór o praworządność i budżet w Radzie UE. Ustępstwa wobec Polski nie spodobaty sie niektórym ministrom (Dispute over the rule of law and budget in the Council of the EU. Some ministers did not like concessions to Poland), „Gazeta Wyborcza”, 18.02.2020. 
calling for the need for moral renewal of the $\mathrm{EU}^{11}$ in order to obtain the greatest possible organizational and financial support saving the economy and the workplace. Besides, the European Union itself creates instruments to encourage greater activity of member states in the fight against pandemics. The examples are the European Social Fund Plus $(\mathrm{ESF}+)$, which would also finance health care programs, ${ }^{12}$ or the recent decision to provide Poland with nearly EUR 13 billion to protect health and jobs. The adoption of the conservative scenario of European policy would result from a pragmatic balance of profits and losses. Essentially, it is one of the most realistic concepts for the near future.

The last and at the same time the least realistic of the scenarios is that Poland will completely change the strategy of conducting European policy from confrontational or conservative to a more active and prointegration one, while maintaining a realistic approach to the activities of European institutions. In this situation, the authorities in Warsaw would have to completely abandon reforms carried out in internal policy, which in principle would be admitting the mistake and agreeing with European institutions, e.g. on the rule of law in Poland. It would also require changes in the legal provisions of internal law in Poland introduced in recent years, which were objected by European institutions as well as selected member states, such as France. In this scenario, Poland would basically have to return to the European policy model from 2007-2015, i.e. building a coalition in the EU based on Berlin and France. In this context, it would be real for Poland to take Britain's place in the European Union and thus enter the first league of member states and have real influence on the decisions-making process. However, this would mean a total negation of the achievements of 2015-2020 in Polish internal and foreign policy. In the context of current political conditions in Poland, this scenario is actually impossible to implement. The complete change of direction of the policy towards Europe is possible only as a result of change of political

11 Such slogans appeared, i.a. in the context of Hungary and Poland's cooperation on the forum of the Visegrad Group, more on this: A. Chojan, Grupa Wyszehradzka w polityce zagranicznej Polski - między wspótpraca a rywalizacja (The Visegrad Group in Poland's foreign policy - between cooperation and competition), „Biuletyn Zakładu Europeistyki ISP PAN", no. 4/2016; A. Chojan, Polityka zagraniczna i bezpieczeństwa UE z perspektywy państw Grupy Wyszehradzkiej (EU Foreign and Security Policy from the perspective of the Visegrad Group countries), in: Globalna Strategia na rzecz Polityki Zagranicznej i Bezpieczeństwa Unii Europejskiej - wybrane aspekty i uwarunkowania (Global Strategy for the European Union's Foreign and Security Policy - selected aspects and conditions), ed. M.J. Tomaszyk, Wydawnictwo Naukowe WNPiD UAM, Poznań 2017.

${ }_{12}$ Zdrowie a fundusze strukturalne (Health and Structural Funds), Komisja Europejska, https://ec.europa.eu/health/funding/future_health_budget_pl (access 10.04.2020). 
groups ruling Poland through democratic elections, and thus not earlier than in three years.

\section{Conclusions}

Brexit is both an opportunity and a challenge for the European Union and its member states. In the context of the member states it is particularly important for countries such as Poland, which from a formal and legal point of view lost, when the British left the Union, and their position has weakened comparing to the biggest countries. Each of the member states must redefine its strategy in the EU. We can already see some capitals trying to take Britain's place. It is said that the "dark horse" of these intraEU games may be the Netherlands, especially since some of the companies that had their headquarters in Britain are moving to the Netherlands ${ }^{13}$. In the context of Poland, it must be clearly stated that Warsaw does not use Brexit to strengthen its position in the EU, or move to a higher level in the decision-making process. In 2016 Poland made a mistake and focused on relations with the UK. Along with the subsequent "support" of the British in divorce negotiations, it will basically close Warsaw's possibility of participating in the division of "trophies" in the European Union. Nevertheless, the authorities in Poland will have to quickly determine how to pursue policy towards Europe already in post-Brexit political reality in Europe, primarily for the benefit of the Poles. This is not about a complete change of course and presenting Euro-enthusiastic attitudes without proper reflection, as it was already done in earlier periods of Polish membership in the EU but, above all, about a skillful selection of instruments to achieve the assumed goals important from the perspective of Poland and the entire European Union.

\section{References}

Bielecki T., Spór o praworzadność i budżet w Radzie UE. Ustępstwa wobec Polski nie spodobaty sie niektórym ministrom (Dispute over the rule of law and budget in the Council of the EU. Some ministers did not like concessions to Poland), „Gazeta Wyborcza”, 18.02.2020.

Chojan A., Grupa Wyszehradzka w polityce zagranicznej Polski - między wspótpraca a rywalizacja (The Visegrad Group in Poland's foreign policy

13 Firmy przenosza się z Wielkiej Brytanii do Holandii z powodu brexitu (Companies are moving from the UK to the Netherlands due to Brexit), https://www.polskieradio24. pl/5/1223/Artykul/2359683,Firmy-przenosza-sie-z-Wielkiej-Brytanii-do-Holandii-z-powodu-brexitu, (access 11.04.2020). 
- between cooperation and competition), „Biuletyn Zakładu Europeistyki ISP PAN", no. 4/2016.

Chojan A., Polityka zagraniczna i bezpieczeństwa UE z perspektywy państw Grupy Wyszehradzkiej (EU Foreign and Security Policy from the perspective of the Visegrad Group countries), in: Globalna Strategia na rzecz Polityki Zagranicznej i Bezpieczeństwa Unii Europejskiej - wybrane aspekty $i$ uwarunkowania (Global Strategy for the European Union's Foreign and Security Policy - selected aspects and conditions), ed. M.J. Tomaszyk, Wydawnictwo Naukowe WNPiD UAM, Poznań 2017.

Cianciara A.K., $W$ poszukiwaniu alternatywnych modeli integracji: Europa jako klub klubów (In search of alternative integration models: Europe as a club of clubs), „Myśl Ekonomiczna i Polityczna”, no. 4/2015.

Dahl M., Skomorokhova Y., The Balance of Power in the European Union after Brexit, „Studia Europaea” 2017, DOI: https://doi.org/10.24193/ subbeuropaea.2017.3.12.

EU speech at Bloomberg, UK government's website, https://www.gov.uk/ government/speeches/eu-speech-at-bloomberg (access 10.04.2020).

Firmy przenoszq sięz Wielkiej Brytanii do Holandiizpowodu brexitu (Companies are moving from the UK to the Netherlands due to Brexit), https://www. polskieradio24.pl/5/1223/Artykul/2359683,Firmy-przenosza-sie-zWielkiej-Brytanii-do-Holandii-z-powodu-brexitu (access 11.04.2020).

Fiszer J.M., Szanse i zagrożenia dla Unii Europejskiej po brexicie. Implikacje dla Polski (Opportunities and threats for the European Union after Brexit. Implications for Poland), „Myśl Ekonomiczna i Polityczna”, no. 4/2017.

Fiszer J.M., Unia Europejska dziś i jej niepewna przysztość. Częśc I (The European Union today and its uncertain future. Part I.), ,Rocznik Integracji Europejskiej", no. 9/2015, DOI: https://doi.org/10.14746/rie.2015.9.3.

Information of the Minister of Foreign Affairs on Polish Foreign Policy in 2016.

Kearns I., Collapse: Europe After The European Union, Biteback Publishing, London 2018.

Kleinowski M., The impact of Brexit on the member states' ability to build blocking coalitions in the Council, „Środkowoeuropejskie Studia Polityczne", no. 2/2019, DOI: https://doi.org/10.14746/ssp.2019.2.1.

Orłowski W., Scenariusze rozwoju Unii Europejskiej w kontekście zmian globalnych (European Union development scenarios in the context of global changes), in: Unia Europejska. Dylematy XXI wieku (European Union. 21st century dilemmas), eds. A. Kukliński, J. Woźniak, Urząd Marszałkowski Województwa Małopolskiego, Kraków 2011.

Postrzeganie Unii Europejskiej i jej instytucji (Perception of the European Union and its institutions), „Komunikat z badań CBOS”, no. 32/2020. 
Szymańska J., Szczepanik M., Reakcja Unii Europejskiej na epidemię korona wirusa (The European Union's response to the Covid 19 epidemic), „Biuletyn PISM", March 17, 2020.

Szymańska J., Zaręba Sz., Wplyw brexitu na gtosowanie w Radzie UE (The impact of Brexit on voting in the EU Council), „Biuletyn PISM”, 8.04.2019.

Thies W.J., Is the EU Collapsing?, „International Studies Review”, vol. 14, no. 2/2012, DOI: https://doi.org/10.1111/j.1468-2486.2012.01110.x.

Zdrowie a fundusze strukturalne (Health and structural funds), Komisja Europejska, https://ec.europa.eu/health/funding/future_health_budget_pl (access 10.04.2020). 